(27)海域の鼠酸摔化て上る無生物底泥の

発生の条作てつして

DEVELOPMENT CONDITION ON SUMMER

DEFAUNATION DUE TO OXYGEN DEPLETION

I N INNER BAY

$\begin{array}{cc}\text { 細川恭史* } & \text { 堀江 㔀* } \\ \text { Yasushi HOSOKAWA*, } & \text { Takeshi HORIE* }\end{array}$

ABSTRACT: The growth of the temporal defaunation on the bottom sediment of ten occures in eutrop hic inner bays during oxygen depletion period in sunmer. The probability of the defaunation is tried to estimate under some assumptions. Paraprionospio sp.A-type is selected as a typical spiece, which is well-known as an organic pollution indicator and a dominant polychaetain most eutrophic bays. The physiological tolerance to low oxygen concentration is examined to get the dose-responce relationship. At $20^{\circ} \mathrm{C}$, respiration rate decreases below $3 \mathrm{mg} / 1$ D. 0 .

concentration. But high survivorship is observed for the low oxygen condition. The tolerance. limit is estimated as "D.0. concentration below $2 \mathrm{mg} / 1$ maintained for more than 2 days." Change of D.0. concentration under the thermal stratification is also analyzed using the continuous observation data in Osaka Bay. The long-term trend in the lower layer is deeply related to the development of the vertical stratification. The short-term fluctuations are related mainly to the small mixing. Applying the same magnitude of the observed fluctuations, probability of the tolerance condition is calculated. Estimated probability is rather low comparing to the seasonal occerance. Reduced substances on the bottom serface under anaerobic condition should be more effective rather than oxygen depletion itself in the bottom water.

KEYWORDS : defaunation, tolerance to low D.0., Paraprionospio sp., oxygen depletion

\title{
1.はじめに
}

富栄盖化した内湾では，夏期に成屏が発達すると底㴔の貧酸素化が進み，一時的で㳉あれ大型底生生物の 存在しない無生物底泥域が発生する。無生物域は，湾奥部の有機質に富む泥質底泥に発生し易い。有楼質底 泥域では底生生物相は単純化し，少種の生物が高密度に生息するようになる。有㙨算底泥に特徽的な烈占種 としては多毛類が多く，それ目体の資源偭值は小さいが，(1沈降有機粒子の分解者，(2)他の底生生物や底魚 の铒，(3)生物的底泥転耕などの底泥酸化促進 等の働きがあり，何よりも劣悪な条件下での最終生存者とし て重要である。ここでは，ほぼ毎夏生起する現象を対象に，発生の条件を個体の生理反忘に求め，現場での 発生条件の生起可能性を時系列観测デーょり考えてみた。

2.ヨツバネスビオの貧踆素耐性実験

2. 1 内湓有傤底泥域での底生生物

海底の底生生物は，一定の種類が特定の環境・場所に群集を成して生息していることが知られている。シ

* 遇輸省港浢技術研究所 Port and Harbour Research Institute, Ministry of Transport 
ズクガイ群集，ヨツバネスビオ群集等は，内湾性の強い海域の有機質泥に特有の群集として分類される。な かでも多毛類のヨツバネスビオ（Paraprionospiesp. A type)は，有機質に污濁された饵細泥筫に対する指 標底生生物として知られており，内湾浅海に卓越してみられる。底生生物の分布や住分けは，生態学的に群 集の生活特性から説明が試みられている。図一1に示す大阪湾西宮防波堤沖のA地点（水深 $16 \mathrm{~m}$ ）付近 2 - 3 筒所での昭和 58 年 4 月以降約 2 年間の底生生物の個体数の変化を図-2に示す。図に法同地点の底上 $2 \mathrm{~m}$ でのD Oの変化なども示してある。要期の底層貧酸素化にともない，毎年6-9月に著しく個体数が減 少し，秋以降に再び個体数が回復していることが判る。個体数の大半を多毛類が占めているが，このうちの 8割程度がヨツバネスビオである。

2. 2 ヨツバネスビオの特徵

寿命は，150日-1年とされ，夏から冬にかけて産卵する。約 1 䈏月の浮遊期を経て幼体は着底し，着 底後早いむのでは 1 箇月で抱卵するものもあるとされる生活史の短い底生生物である。成体は体長数mm- 1

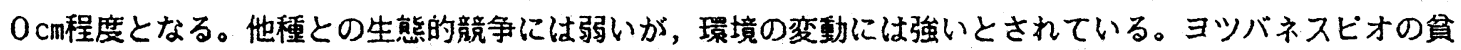
煙素耐性の実験列は，余り見当たらないが，好適塩分範囲は30-40\%。，好適温度範囲は5-2 $0^{\circ} \mathrm{C}$ と 云われている。

\section{3 ヨツバネスビオの盆酸素耐性実験}

生物活性として呼吸による酸瑟消資を選び，貣酸素化に伴う呼吸速度の低下を测定した。又生存基盤の悪

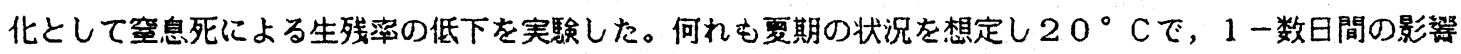
を検討した。他の水算変動や共存物筫の影㖕は十分には考愿されていない。

(A) 方法 ヨツバネスビオA型は昭和61年冬に横浜港にて採取した。海永中でスボイト法により選別を 行い，24時間無投慨飼育後に実験に用いている。呼吸速度は，300ml容の細口ガラスビンに大きさを揃 えて 10 個体ずつ入れ，24時間暗所に静置しビン中のD O濃度の変化より求めた。ビン中の海水は，予め

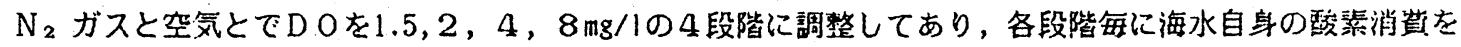
湘定する対照ビンを設けた。苗酸素に対する耐性実験は，600ml容のガラスビンに 10 個体ずつ入れ，7 2 時間暗所にて静置して行った。24時間ごとに，転倒䫓微鏡を用いて個体の動きを覞察し，エラの動きの

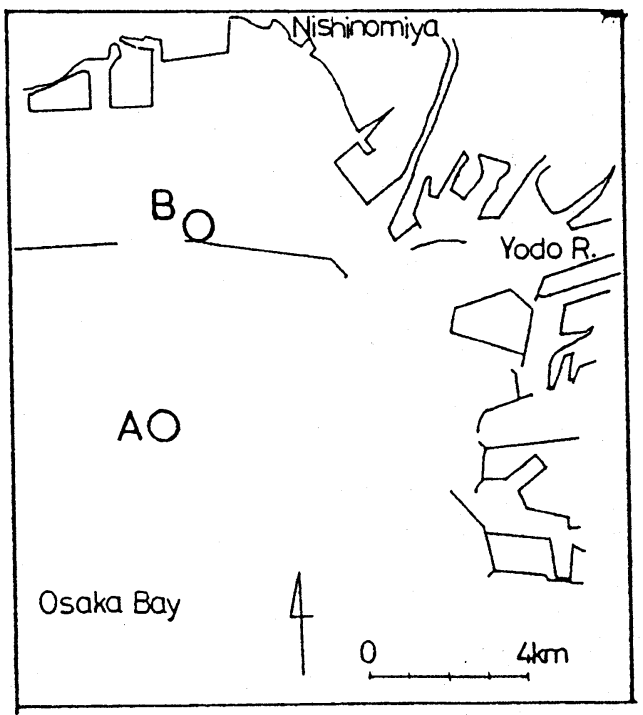

図-1 大阪湾西宫沖钼測位嘼図
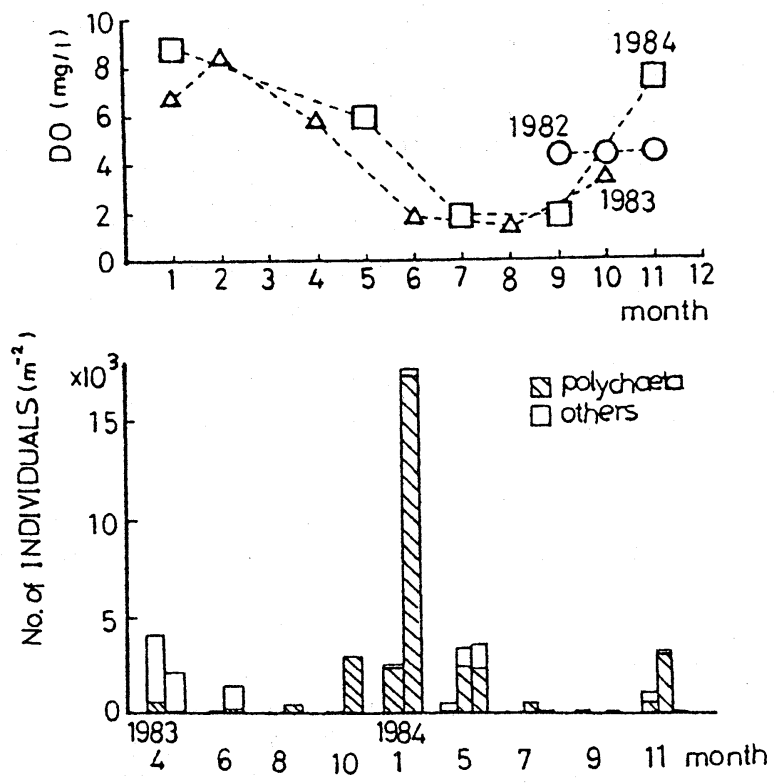

図-2 大阪济A地点に打ける季節変化 
止まった死亡個体を計数した。D Oは，1，1.5，2，2.5，3mg/1の5段階に調整してある。開始時と終 了時にD ○を測定すると共に，終了時すべてのビンをばっきし数時間後に生残個体を検鏡により確認し最終 生残率とした。海水は32\%っのものを $1 \mu \mathrm{m}$ 万紙で澺過し用いている。又何れの実験でも固体の湿重量を 测定した。昭和 62 年冬には，培䖯ビンに61 容のガラスビンを用い抗生物質（ストレプトマイシン）を硫 酸塩として0.5 mg/lとなる様に添加して耐性実験を追加して行った。

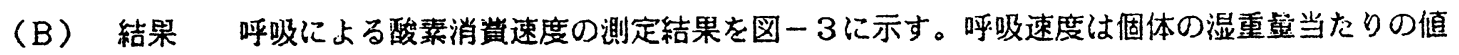
で表してある。1 個体の平均湿重量が $10 \mathrm{mg}$ 以上のケースを白丸で示してある。D O 算度に関わらず一定の

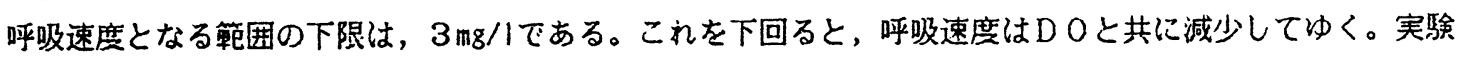
開始時D 01.2mg/1 では呼吸は極めて小さいが，このケースでも全個体の生存が磪認され窒息死は起きてい ない。分酸素酎性实験では，実験開始時 D Oが0.9mg/1 のケースで 24 時間後でも全個体の生残が見られ， 運動は不活発であるが即死とならないことが判った。しかし，48時間後には2-4割，72時間後には5 -9割が死亡し，2日を経過すると急激に死亡が進行することが判る。開始時D $01 \mathrm{mg} / 1$ の生残率の経時変

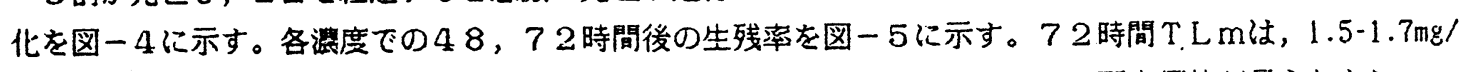
1となる。一方，抗生物質添加ケースでは，D 0 0.3-0.5ing/1 でも4日目までは死亡個体が見られない。

2.4 ヨツバネスビオの䈗素に対する反応のまとめ

(1). 通常の呼吸が阻害され始めるD O摆度は, $20^{\circ} \mathrm{CC゙} 3 \mathrm{mg} / 1$ 。(2). D 0 1mg// でも1日では死亡しな

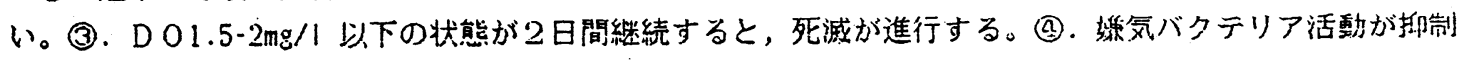
されると，更に長期にわたり生残する。更に詳しい検討が必要だが，ここでは $12 \mathrm{mg} / 1$ 以下の状態が2日間 継続すること」を死咸の条件として考えることとする。

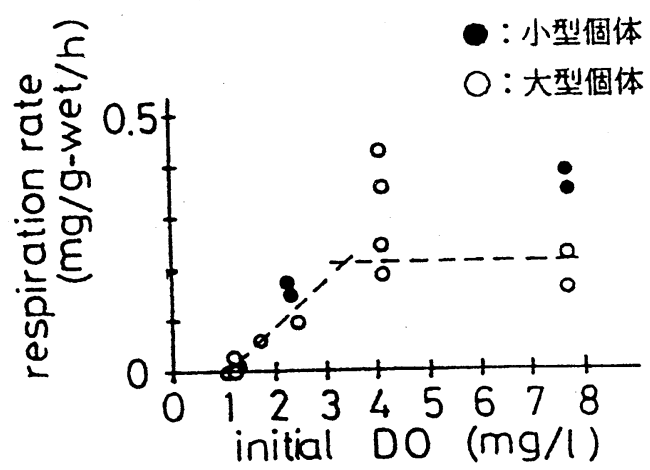

図一－＼cjkstart呼吸速度のD O 灌度に対する变化

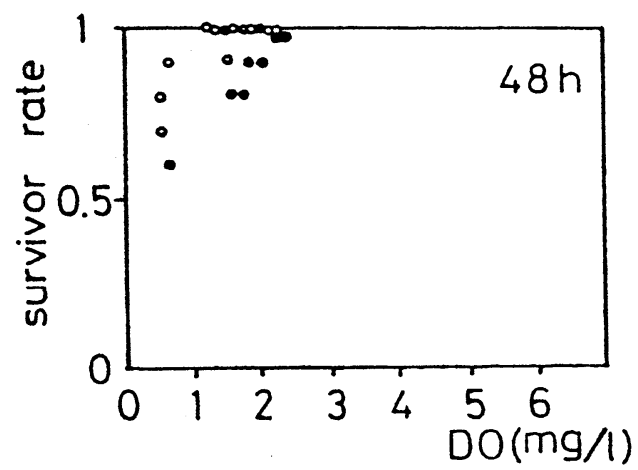

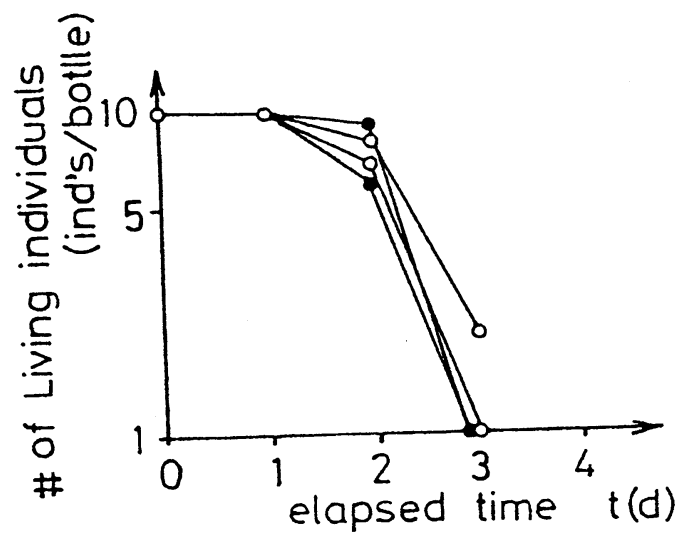

図-4 ヨツバネスビオの死滅過程 (DO1mg/l)

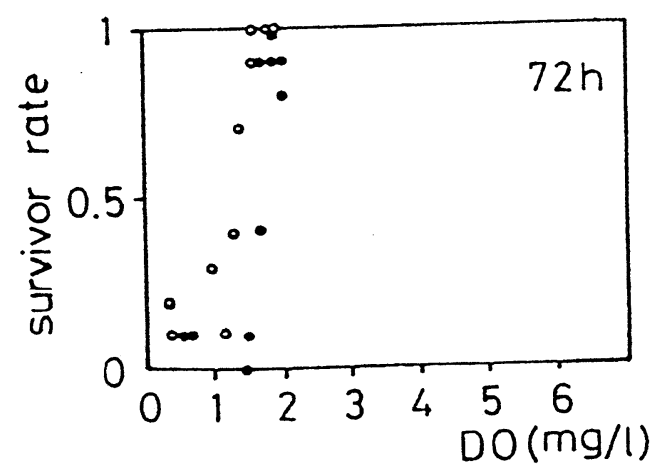

図ー5 ヨッバネスビオの筫酸に対する生残率 


\section{3. 下绝D Oの変動}

\section{1 D 0の自動眖測}

图一 1 のB地点（西宮防波堤内, 水深10m）で昭和 60 年に水简自動観测が試みられた。測定水深仙 $1 \mathrm{~m}, 4$ mの2 屏である。測定項目は多岐にわたっているが，下層D Oは7月 16 日より約 30 日閒にわたり毎正時 に測定された。 8 月 $5 ， 11$ 日に少降雨を見たが他は良く晴れて, 成㴓が発達していた。長期間漙続して測 得できた7月 27 日 15 時から 8 月 17 日11 時までの 20 日間の下層D Oの变化を図一 6 に示す。13日

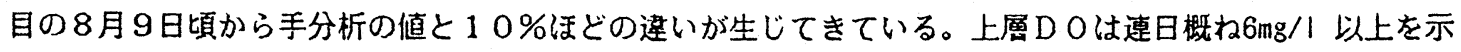
した。 $4 \mathrm{~m}$ の測定位畗は，ほぼ下層に属しているが，上下の混合状況によっては成層の境界位置となること む苛る。

図一6を見ると，変動の日周性が明膫でなく，日の出前に極小・午後に極大になると云った倾向はうかがえ ない。11日目までの 256 個の測得值のバワースペクトルを図ー7に示す。36，23，11時間辺りに ビークが見られ，5日以上の長い周期の寄与む大きい。23時間の変動は, 他の項目や他の測定期間でも見

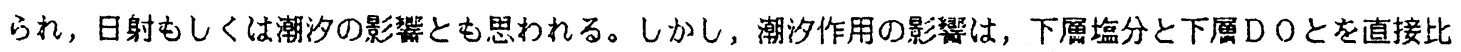
較して屯低い相関しか得られない。成愿の強さとして上下屏の程分差を求めると図一8のようになる。図一 6 に破線で示した 23 時間移動平均の経時変化と良く似た変動となる。成屏の強さは湖汐・日射・降雨・風 などに関係し，周期性は明碓でない。

成層の発達に起因するゆっくりとした平均湛度の変動を除志，1日問以下程度の変動を取り出してみる。2 3 時間移動平均值をもとの測得値より差し引いた残差を图一6から読むと，成虽が安定し平均港度が低下す

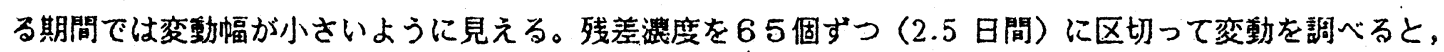
僅かながら 11 時間程度の周期にビークが見られる。1時間前の値とも弱い関係があり, ランダムな変動と は見なせない場合もある。変動の祭準偏差（ $\mathrm{s} ）$ は0.78-1.51mg/l の範囲にある。

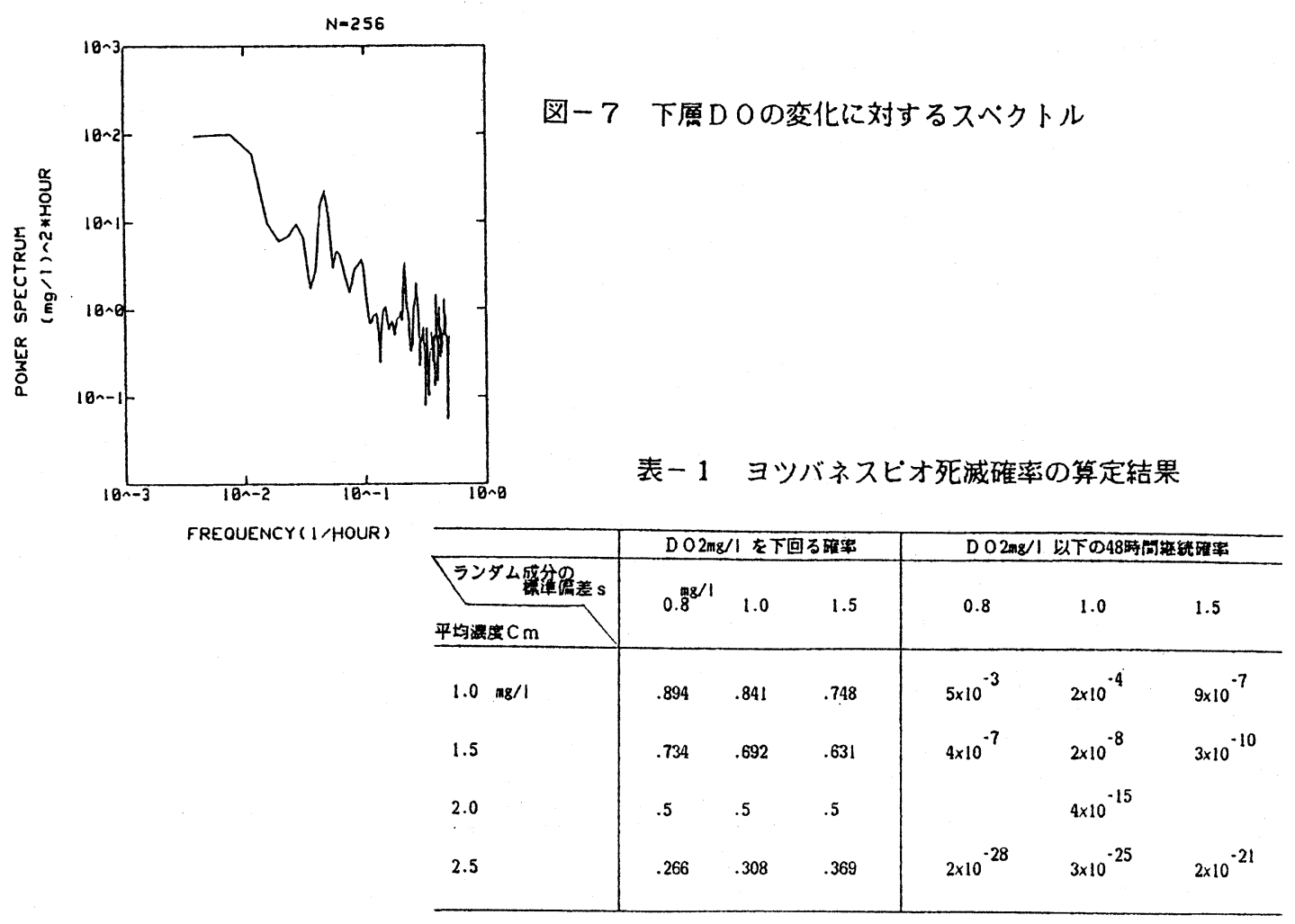




\section{2 简易なモデルによる死減確率の算定}

ここでは最も简単に下屏D ○の变化を次のようにモデ化した。

$$
\mathrm{Ct}=\mathrm{Cm}+\mathrm{Et}, \quad \mathrm{Et} \sim \mathrm{NID}\left(0, s^{2}\right)
$$

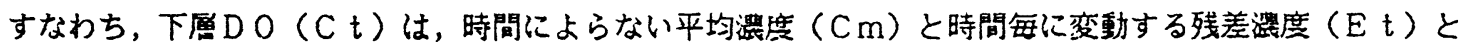
の和であり，残差湛度の变動は平均值 0 ，標準偏差 $s$ のワイトノイズで表せる。sについては，前出の測 定例より0.8-1.5mg// を採用した。 $\mathrm{Cm}$ 的2-3日では一定であり所与の値として1-2.5mg/I を与えた。D

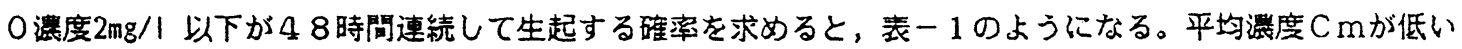

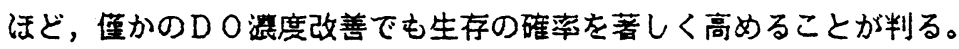

简単なモテルであり，バラメータも比較的浅い水深での測定值に基ずいているから表一1の值そのものは 余り信用か置けない。それでも，ここでの值 $10^{-3}-10^{-10}$ は，毎年夏期に生起する現象に対しては小さす

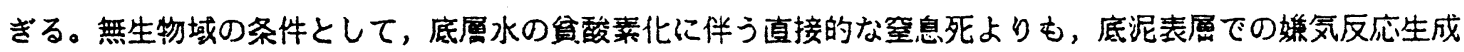
物による毒性のほうがより重要である可能性がある。

底生生物の培砬・選別には北森良之介博士の御指等を得た。記して感谢いたします。

参考文献 1.上野ら、ベントス研会誌23，（1982） 2. H.Tsutsumiら，Publ.Allakusa Mar.Biol.Lat., 7(1),(1983)

3. 村上, 港研報告, $26(2),(1987)$

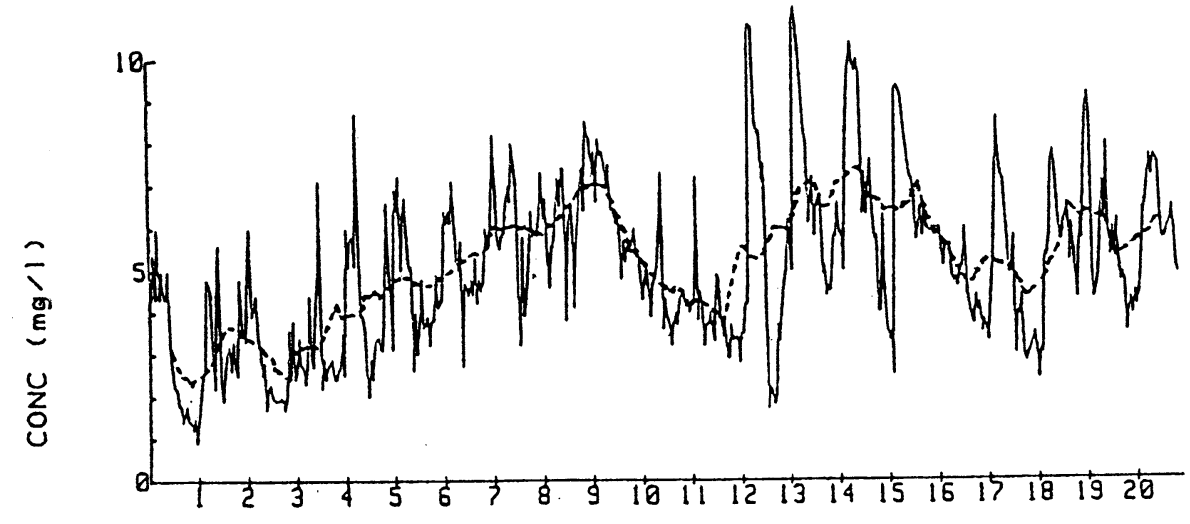

TIME (DAY)

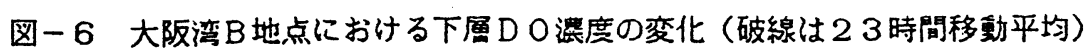

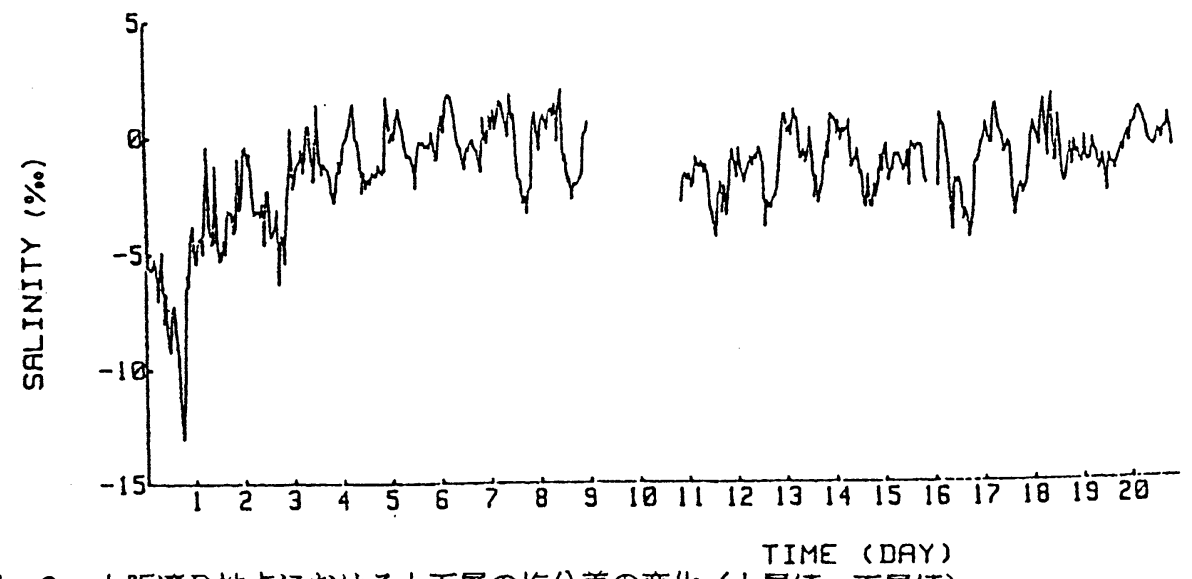

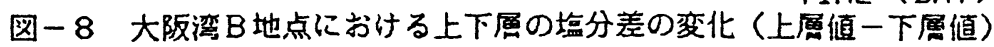

